\title{
BIRTH CONTROL AND A NEW BIRTH OF FREEDOM
}

\begin{abstract}
HarrIet F. PILPEL*
The author analyzes Griswold v. Connecticut and other recent developments in the birth control movement and explains their significance for constitutional theory. The Griswold case raised the principle of voluntary family planning to the status of a constitutional right. It also recognized the standing of those in the helping professions to assert the rights of their patients and clients. The Court's recognition of a right of privacy and restoration of meaning to the ninth and tenth amendments may be a protection against the increasing threat of a "big brother" society. Recent administrative and judicial decisions emasculating the Comstock laws demonstrate the importance of constitutional checks and balances. The ultimate question posed by the Griswold case is whether it will be recognized that the government has an affirmative obligation to make the exercise of constitutional rights possible.
\end{abstract}

The year 1965 marked a turning point in the birth control movement and in its wake some significant new aspects and implications in the constitutional law of personal freedom. In June of that year the United States Supreme Court struck down a Connecticut law prohibiting the use of contraceptives that had been on the statute books for seventy-five years. ${ }^{1}$ The decision culminated twenty-five years of legal battling. ${ }^{2}$ In the same year and in the years directly preceding and the year following the Supreme Court decision, many state and federal government agencies and officials-from the President of the United States on down-acknowledged not only the legality of birth control but also the urgent need to make birth control available to the underprivileged sectors of the population through public agencies. By 1966, tax-supported birth control services were in existence, to a greater or lesser extent in forty-two states and the District of $\mathrm{Co}$ lumbia.

Developments ranged from repeated encouragement of birth con-

* Member of the New York Bar and member of the national boards of directors of the American Civil Liberties Union and the Planned Parenthood Federation of America, Inc.

1 Griswold v. Connecticut, 381 U.S. 479 (1965).

2 Poe v. Ullman, 367 U.S. 497 (1961); Tileston v. Ullman, 129 Conn. 84, 26 A.2d 582 (1942), appeal dismissed, 318 U.S. 44 (1943); State v. Nelson, 126 Conn. 412, 11 A.2d 856 (1940). 
trol activities by President Johnson ${ }^{3}$ to the repeal or the amendment of many state laws which had stood in the way of publicly financed birth control programs. ${ }^{4}$ In 1966 a Deputy Assistant Secretary for Science and Population was appointed by the Secretary of Health, Education and Welfare to centralize and stress the Department's birth control activities. ${ }^{5}$ Legislation was introduced into Congress by Senator Tydings ${ }^{6}$ and others calling for substantial and annually increasing federal financial aid to state, local and private agencies in the birth control field.

The Supreme Court decision and to a lesser extent the legislative, administrative and policy changes which preceded and followed it signal important developments, now only in their infancy, in our basic concepts of government and constitutional law. I propose briefly to discuss to some of these developments and some of their implications for constitutional theory. They presage a necessary reevaluation of old concepts, necessary, that is, if liberty is to remain a meaningful concept in the daily lives of Americans, today and tomorrow.

3 In his Special Message to Congress on Health and Education, March 1, 1966, 112 Cong. Rec. 4239, President Johnson made the following statement:

We have a growing concern to foster the integrity of the family, and the opportunity for each child. It is essential that all families have access to information and services that will allow freedom to choose the number and spacing of their children within the dictates of individual conscience.

In the fiscal 1967 budget, I have requested a sizeable increase in the funds available for research, training, and services in this field. The National Institute for Child Health and Human Development will expand its own research and its grant program to study human reproduction. The Children's Bureau and the Office of Economic Opportunity will support family planning in the maternal and infant care programs in local communities when requested. State agencies will be aided by Federal welfare funds to provide family planning services to mothers.

Other statements made by President Johnson encouraging birth control are contained in the following speeches: Twentieth Anniversary of the United Nations at San Francisco, June 25, 1966; Swearing in Ceremony of John W. Gardner as Secretary of Health, Education, and Welfare, 1 Weekly Comp. of Pres. Documents 104 (1965); State of the Union Address before Congress, 112 Cong. Rec. 129 (1966); Foreign Aid Program message to Congress, 112 Cong. Rec. 1630 (1966); International Education and Health message, 112 Cong. Rec. 1652 (1966); War on Hunger message, 112 Cong. Rec. 2703 (1966).

4 The most recent states to repeal anti-birth control legislation or to enact laws authorizing birth control activities included Alaska, California, Colorado, Florida, Georgia, Illinois, Indiana, Iowa, Kansas, Massachusetts, Michigan, Minnesota, Nevada, New York, Ohio, and West Virginia. Planned Parenthood, Ending Comstockery in America I-V (1965-66).

5 N.Y. Times, May 6, 1966, p. 22, col. 3, Late City Edition.

6 S. 2993, 89th Cong., 2d Sess. (1966). 


\section{The Birth Control Victory: The Triumph of Voluntarism}

In June of 1965 the United States Supreme Court held unconstitutional the Connecticut use statute, reversing the convictions as accessories to the crime of use of Dr. C. Lee Buxton, the Medical Director of the New Haven Planned Parenthood Center, and of Mrs. Estelle Griswold, the Executive Director of the Center. ${ }^{7}$ Different Justices took different paths to reach this result. The majority opinion written by Justice Douglas held that the Connecticut law infringed "the zone of privacy" created by the penumbra of various constitutional guarantees. ${ }^{8}$ It would seem, however, that in the specific context of birth control the major significance of the seven to two decision is that it established a principle of voluntarism. This principle recognizes and protects the right of parents to "choose the number and spacing of their children within the dictates of individual conscience." As Mr. Justice Goldberg stated in his concurring opinion:

[T] otalitarian limitation of family size . .. is at complete variance with our constitutional concepts. . . . If, upon a showing of a slender basis of rationality, a law outlawing voluntary birth control by married persons is valid, then, by the same reasoning, a law requiring compulsory birth control also would seem to be valid. In my view, however, both types of law would unjustifiably intrude upon rights of marital privacy which are constitutionally protected. ${ }^{10}$

Mr. Justice Goldberg spoke not a moment too soon. To paraphrase President Kennedy, this will be either the first generation to make possible the exercise of free choice in the birth control field or it will be the last in which voluntary family planning is possible. The exigencies of expanding populations are such that if the government does not make possible voluntary birth control, compulsory birth control will be increasingly advocated. Already in Mississippi and Georgia bills have been introduced into the legislature which would have punished by fine and/or imprisonment certain classes of persons, such as women on welfare who already have one illegitimate child, who did not obtain birth control advice and assistance. ${ }^{11}$ Already two different California

7 Griswold v. Connecticut, supra note 1.

8 Id. at 485 .

9 President Lyndon B. Johnson, Special Message on Health and Education, March 1. 1966, supra note 3.

10 Griswold v. Connecticut, supra note 1 , at 497.

11 S.B. 1648, Regular Session of Miss. Legislature (1964).

Ironically, Mississippi also has a law which appears to make birth control illegal. Miss. Code $\$ 2289$ (1942). But, so far as this writer knows, the law has never been enforced. 
judges have given without statutory warrant a man and a woman defendants the "choice" between jail and sterilization. ${ }^{12}$ And there have been premonitory rumblings elsewhere. Thus, the New York Times for June 2, 1966 reported:

\section{MOTHER AGREES TO BE STERILIZED}

\section{WOMAN WHO KILLED HER BABY ACCEPTS COURT SUGGESTION}

PHILADELPHIA, June 1-An unwed 24-year-old mother, convicted of killing her four-day old son by dropping him into an incinerator in the apartment building where she lived, has agreed to submit to sterilization.

The woman, Francine Rutledge, took this step yesterday on the strength of a promise by Judge Raymond Pace Alexander of a reduced sentence for murder.

Voluntary sterilization is a method of birth control which should be available to all, rich or poor, who wish no more children. ${ }^{13}$ But the kind of coercion involved where people are made to choose between sterilization and jail or a heavier jail sentence would seem to be unconstitutional under the doctrine of voluntarism declared by the Griswold case.

Also, the doctrine of that case throws into question the validity of the compulsory sterilization statutes presently on the statute books of about twenty-eight states. Just recently, Oregon passed a law providing compulsory sterilization for those, among others, in state institutions "who would probably become social menaces or wards of the State." Hitler demonstrated all too clearly what state authority over procreation can and did mean. Totalitarian is too simple a word for it; barbarian would do better. Therefore, if the Griswold decision had done nothing more than establish a constitutional principle of voluntarism in reference to procreation, it would have been a major achievement. But, in fact, it established or foreshadowed the establishment of a number of other constitutional realizations.

12 Hernandez v. State, Santa Barbara Munic. Ct. May 20, 1966, in Long Beach California Independent, May 21, 1966, p. 1; Andrada v. State Pasadena Munic. Ct. Jan., 1964, in N.Y. Post, Oct. 25, 1964, Magazine Sec., p. 6. col. 1. See also Graham, The Law: 'Sterilization or Jail,' N.Y. Times, May 29, 1966, p. 8E, col. 1, Late City Edition.

13 H.B. 60, Georgia Legislature (1966), authorizes and provides a procedure for voluntary surgical sterilization. See also Code of Va. ch. $32, \S \S 423-427$ (1964); N. Car. Gen. Stat. \$§ 190-271 (Supp. 1965).

14 Ore. Rev. Stat. \& 436.050 (1965). 


\section{The Right of Physicians and Others in the Helping} Professions to Assert the Rights of Their Patients AND Clients

One of the great obstacles to the obtaining of what Professor Charles Reich of the Yale Law School has called "a bill of rights for the disinherited" has been the procedural and technical rule that a person may not challenge the constitutionality of government action unless that action directly impinges on his own constitutional rights. ${ }^{15}$ The United States Supreme Court has found this rule increasingly hard to live with and has already departed from it in a number of cases. For example, a white seller of real property was able successfully to attack the validity of a restrictive covenant directed against Negroes. ${ }^{16}$ In the Connecticut birth control case, Justice Douglas enunciated what in effect was another departure from the rule: "We think that appellants have standing to raise the constitutional rights of the married people with whom they had a professional relationship."17 While little attention has been paid to this phase of the case, a substantial part of the briefs and arguments in the Supreme Court was directed to it and its importance cannot be overstated. For in today's world, the "disinherited," the welfare recipients, and the poverty groups are usually not able to assert their constitutional rights without further jeopardizing their extremely tenuous economic position. Therefore, it is likely that only if physicians, public health workers, social welfare workers and other helping professional personnel are legally able to assert the rights of the underprivileged, will those rights be asserted at all. The midnight raids on the homes of mothers receiving federal-aid-to-dependent-children money in various states, including Illinois and California, have aroused some protest on the part of those who know about them. ${ }^{18}$ As a practical matter, however, judicial remedies have been sought, if at all, by those who serve the poor and not by the poor themselves. ${ }^{19}$ Fear of losing aid is a very effective deterrent to those who need that aid to live.

15 Reich, "Individual Rights and Social Welfare: The Emerging Legal Issues," 74 Yale L.J. 1245 (1965).

16 Barrows v. Jackson, 346 U.S. 249 (1953).

17 Griswold v. Connecticut, supra note 1 at 481.

18 Reich, "Midnight Welfare Searches and the Social Security Act," 72 Yale L.J. 1347 (1963).

10 See Parrish v. Civil Service Commission of Alameda City, 35 U.S. Law Week 2021 (Calif. Ct. of App. 1966), holding that a social worker may be legally discharged for refusing to participate in mass search for unauthorized males in homes of welfare recipients. 


\section{The Emergence of a Constitutional "Right of Privacy"}

Reference has already been made to the fact that the majority decision of the Court in the Connecticut birth control case was premised on there being a constitutionally protected zone of privacy which the government may not enter. Here, too, the implications of the decision obviously reach far beyond the area of birth control and procreation. Justice Douglas found support for a constitutionally protected right of privacy in some prior cases. These cases had established the right to educate one's children as one chooses, ${ }^{20}$ the right to study the German language in a private school, ${ }^{21}$ the right to read, ${ }^{22}$ the freedom of the entire university community, ${ }^{23}$ freedom to associate and privacy in one's association..$^{24}$ The cases, said Justice Douglas, establishing rights such as these "suggest that specific guarantees in the Bill of Rights have penumbras, formed by emanations from those guarantees that help give them life and substance. . . Various guarantees create zones of privacy."25 He concluded that the "present case, then, concerns a relationship lying within the zone of privacy created by several fundamental Constitutional guarantees . . . a right of privacy older than the Bill of Rights."

At this time it is, of course, impossible to predict either the outer or the inner limits of this "right of privacy." The new right should not, in any event, be confused with what, until now, most lawyers understood was meant by the phrase "right of privacy," namely, the right of a private citizen to prevent his name and picture from being used for advertising or commercial purposes, or in intimate, private, or fictionalized contexts without his consent. ${ }^{27}$ This right is a right of privacy only in the sense that it is a right against publicity and is no part of the constitutional "right of privacy" declared in the Griswold case. The Griswold decision indicates that the constitutional right of privacy may have a far-reaching effect. Its adumbration and proliferation by the courts and perhaps by legislatures may prove to be a major weapon in our ever-present struggle against a "big brother" society.

20 Pierce v. Society of Sisters, 268 U.S. 510 (1924).

21 Meyer v. Nebraska, 262 U.S. 390 (1923).

22 Martin v. Struthers, 319 U.S. 141 (1943).

23 Baggett v. Bullett, 377 U.S. 360 (1964); Barenblatt v. U.S., 360 U.S. 109 (1959); Sweezy v. New Hampshire, 354 U.S. 234 (1957).

24 N.A.A.C.P. v. Alabama, 357 U.S. 449 (1958).

25 Griswold v. Connecticut, supra note 1, at 484.

$26 I d$. at $485-6$.

27 Prosser, Law of Torts, $\S 112$ (3d ed. 1964). The recognition of this right of privacy originated with Warren \& Brandeis, "The Right of Privacy," 4 Harv. I. Rev. 193 (1890). 
Just as technological and scientific progress have made it possible for us to destroy all life on this planet, so, too, technological and scientific progress in such forms as electronic-snooping devices and mindinfluencing drugs have made it possible to destroy all privacy. The emergence of a constitutional right of privacy, that right first given utterance in the birth control case, may indeed save us from an Orwellian 1984.

\section{The Rebirth of the Ninth and Tenth Amendments}

Justices Douglas and Goldberg, in particular, looked to the ninth and tenth amendments for support of their theory that there is a hard core area of individual liberty that is and should be secure from all governmental intrusion..$^{28}$ Prior to the Griswold decision, judges and lawyers in general regarded these two amendments as being substantially meaningless. ${ }^{29}$

Some commentators have expressed the view that the reasoning of Griswold was called into being by the "hard" case presented and that "hard cases always make bad law." Others have opined that in its declaration of a right of privacy and its reliance on the hitherto overlooked ninth and tenth amendments, the Court has opened the way to a new basis for protecting fundamental human rights. Only time will tell which interpretation is correct. One thing, however, is clear. By referring to the ninth and tenth amendments, the Court has at least restored them to some significance in our constitutional scheme. With totalitarian ideologies threatening to take over, and indeed taking over, large parts of the world, there is something reassuring about the declared concept that there are rights that are retained by the people. Certain rights, of which a right of privacy is only one, have been made necessary by twentieth century realities. These rights may not fit into the precise wording of the Bill of Rights but they nevertheless belong there. Justices Black and Stewart dissented in Griswold because the rights involved did not fit in any of the specific guarantees of the first ten amendments. But the majority of the court by suggesting a variety of different theories to expand the protection offered by the Bill of Rights took a giant step in the direction of adapting these guarantees of personal freedom to the world today.

28 Griswold v. Connecticut, supra note 1, at 484, 87.

29 Justice Goldberg found support for his interpretation in Redlich, "Are There 'Certain Rights Retained by the People'?" 37 N.Y.U.L. Rev. 787 (1962); Patterson, "The Forgotten Ninth Amendment" (1965); Kelsey, "The Ninth Amendment of the Federal Constitution," 11 Ind. L.J. 309 (1936). 


\section{Checks And Balances: A New Meaning For The Old CONCEPT}

Although the Connecticut birth control case has been the only decision on the merits rendered in the birth control field by the United States Supreme Court, other courts have for decades been struggling with other repressive birth control laws which, like the Connecticut law but not so extreme, emanated from the original federal ban enacted by Congress at the instigation of Anthony Comstock.

Until the early 1960's, virtually every effort to change the state and federal anti-birth control laws on the books had failed. Federal and state legislatures alike had refused to repeal or change the laws, most of which dated back to 1873 or thereabouts. ${ }^{30}$ Indeed, the original federal Comstock laws remain on the federal statute books today, in substantially the same terms as when they were passed. ${ }^{31}$ However, beginning in 1930, federal courts found it untenable to construe these laws literally, for so construed they were absurd, unreasonable and perhaps unconstitutional. For example, in 1930, the Federal Court of Appeals for the Second Circuit stated with reference to the federal laws:

Taken literally, this language would seem to forbid the transportation by mail or common carriage of anything "adapted" in the sense of being suitable or fitted, for preventing conception or for any indecent or immoral purpose, even though the article might also be capable of legitimate uses and the sender in good faith supposed that it would be used only legitimately . . . it would seem reasonable to give the word "adapted" a more limited meaning than that above suggested and to construe the whole phrase "designed, adapted or intended" as requiring an intent on the part of the sender that the article mailed or shipped by common carrier be used for illegal contraception or abortion or for indecent or immoral purposes. ${ }^{32}$

This interpretation was reiterated and strengthened when the same court in 1936 said, with reference to the entire pattern of federal law in this area:

Its design, in our opinion, was not to prevent the importation, sale or carriage by mail of things which might intelligently be employed by conscientious and competent physicians for the purpose of saving life or promoting the well-being of their patients. The word "unlawful" would make this clear as to articles for producing

30 The original Comstock Act, Act of March 3, 1873 ch. 258, 17 Stat. 598 (1873).

3118 U.S.C. $\$ \S 552,1461,1462,1463$ (1952); 19 U.S.C. $\S 1305$ (1952).

32 Youngs Rubber Co. v. C.I. Lee \& Co., 45 F.2d 103, 108 (2d Cir. 1930). 
abortion, and the courts have read an exemption into the act covering such articles even where the word "unlawful" is not used. The same exception should apply to articles for preventing conception. ${ }^{33}$

Finally, the same court put the matter succinctly when it said in 1938: "We have twice decided that contraceptive articles may have lawful uses and that statutes prohibiting them should be read as forbidding them only when unlawfully employed." 34

Since the 1930's and especially within the last few years, many federal governmental agencies have been increasingly active in supporting the distribution of contraceptives and contraceptive information. Among them are various agencies of the Department of Health, Education and Welfare, the Department of Interior, the Agency for International Development, and the Office of Economic Opportunity. ${ }^{35}$

Both Presidents Kennedy and Johnson have characterized population control as a matter of prime national and international importance, and in 1966 former Presidents Harry Truman and Dwight Eisenhower became co-chairmen of the fund raising campaign of the Planned Parenthood Federation.

The present limited range of the Comstock laws became dramatically clear in 1963 when the St. Louis Post Office sought to prevent the mailing of samples of a contraceptive which were being mailed in response to coupons contained in ads appearing in nineteen national magazines with a lay readership of about thirty-one million people. The coupons called for the person filling them out to state if she was married and, if so, when she was married. After many discussions and memoranda, both the Post Office Department and the Justice Department agreed that the samples could, notwithstanding the Comstock laws, be lawfully mailed in the absence of any affirmative showing by the government that they were to be used for an unlawful purpose. ${ }^{36}$ The Customs Department shortly followed suit with a similar ruling. Since it is unlikely that anyone mailing, shipping or importing a contraceptive will indicate that it is to be used for an unlawful purpose, the federal laws on the subject have been "checked and balanced" to the point where, except for the uncertainties they create, they have little, if any, effect on federal birth control programs or the transmission

33 United States v. One Package, 86 F.2d 737, 739 (2d Cir. 1936).

34 United States v. Nicholas, 97 F.2d 510, 512 (2d Cir. 1938).

35 Hearings on S. 1676 Before the Sub-Committee on Foreign Aid Expenditures of the Senate Committee on Government Operations, 89th Cong., 1st Sess., pt. 2-A, at 740 (1965).

36 N.Y. Times, Oct. 24, 1963, p. 30, col. 2, Late City Edition. 
of birth control supplies or information through the mails or in interstate or foreign commerce.

Only about half of the states had anti-birth control laws at any time and most of these, with the exception of Connecticut and Massachusetts, were more or less regulatory rather than prohibitive. When these statutes came before state courts, which they rarely did, they also were generally interpreted not to interfere with such legitimate birth control activities as prescriptions by physicians. By 1966, however, after almost a century of legislative inaction, many of these states, culminating with Massachusetts, ${ }^{37}$ had either repealed the "little Comstock Acts" or had amended them to permit the development and expansion of birth control programs. ${ }^{38}$

The history of anti-birth control legislation in this country is a unique example of the Constitution's built-in system of checks and balances. The courts and executive and administrative officials, faced with the necessity of applying and construing obsolete laws which the legislatures were unable or unwilling to change, managed, except in Connecticut and Massachusetts, to adapt these nineteenth century morality statutes to twentieth century population and birth control realities. Hopefully, a similar development must and will follow in the field of abortion. To such pioneers as Margaret Sanger, Drs. Hannah and Abraham Stone, Morris L. Ernst, and the many others who forged the first legal victories in the birth control field, particular credit is due for this reassuring story of democracy in action.

\section{Does the Government Have an Affirmative Obligation to Make Possible the Exercise of Birth Control?}

As pointed out above, Griswold established the right of voluntarism in family planning. ${ }^{82}$ The establishment of this right was a significant achievement, but what does the right mean to those who have no access to the information or supplies which make birth control possible? Unless the government recognizes an obligation to provide birth control information and supplies where needed, the right of voluntarism will be meaningless to many citizens.

It may be that the Supreme Court will go beyond a laissez faire approach and recognize that a right without the wherewithal to exercise that right is no right at all. Indeed, in some areas, the Court has

37 Mass. Gen. Laws ch. 272, $\S \S 21,21 \mathrm{~A}$ (1966).

38 The most recent states include California, Colorado, Florida, Indiana, Iowa, Kansas, Massachusetts, Michigan, Minnesota, Nevada, New York, and Ohio. Planned Parenthood, Ending Comstockery in America I-V (1956-66).

38 See text accompanying note 9 supra. 
already held that the government has an obligation to make constitutional rights meaningful to the economically deprived. ${ }^{40}$ For example, Gideon v. Wainzeright held that the government must furnish legal representation to persons accused of crime who cannot afford it. ${ }^{41}$ These decisions appear to recognize that in many situations government inaction is identical with government action and therefore subject to the same constitutional guarantees. ${ }^{* 2}$ Arguably, the same reasoning is applicable whenever government inaction prevents citizens from exercising fundamental constitutional rights, including the right of family planning.

The question of government inaction being equivalent to government action is of special significance for those whom Professor Reich calls the "disinherited." In a growing number of contexts, constitutional rights simply do not exist for these people unless the government makes their exercise possible. Perhaps the public's gradual recognition of this fact explains why our ever increasing welfare state is accepting the responsibility of feeding, clothing, and jobbing those among us who would otherwise be starving, naked, and unemployed. The important constitutional question raised by this development, however, is whether the government's assistance to the poor is based on grace or right.

Arguably, fundamental notions of human decency require that the relationship between the government and the poor be based on what Professor Reich has termed "entitlement." When the Constitution and the Bill of Rights were adopted, the danger to liberty was thought to be, and probably was, repressive action by the government. Hence, the Constitution is full of "thou shalt nots" directed against affirmative governmental interference with the basic human rights enumerated in the Constitution. Today, government inaction poses a greater threat to the liberty of many persons than government action. While in the

40 Gideon v. Wainwright, 372 U.S. 335 (1963) (duty to furnish legal counsel); Burns v. Ohio, 360 U.S. 252 (1959) (duty to pay or waive filing fee); Griffin v. Illinois, 351 U.S. 12 (1955) (duty to furnish or waive transcript).

41 Ibid.

42 The possibility of government action and inaction producing identical effects was recognized by Justice Stone many years ago in an entirely different context. In the case of Miller v. Schoene, 276 U.S. 272 (1928), government inaction would result in the destruction of apple trees by a cedar blight. Government action to protect the apple trees, however, would result in the destruction of the cedar trees. Professor Robert I. Hale of Columbia Law School pointed out the significance of this case more than thirty years ago in "Force and the State: A Comparison of Political and Economic Compulsion," 35 Colum. L. Rev. 149 (1935).

43 Reich, "Individual Rights and Social Welfare: The Emerging Legal Issues," 74 Yale L.J. 1245 (1965). 
1780 's and 90's the government accepted little, if any, responsibility for the welfare of its citizens, today the government has undertaken formerly undreamed of welfare responsibilities. Government action has been a response to political expediency not constitutional guarantees. Nevertheless, it may become apparent that the government's assumption of greater responsibilities has created new expectations and rights.

It is too early to predict what will be the long range impact of the Griswold case on United States constitutional theory. Hopefully, it will serve as an important stepping stone in the development of our constitutional scheme. Our Declaration of Independence speaks of it being self-evident that "all men are created equal," that they are "endowed by their Creator with certain inalienable rights" and that "among these are life, liberty and the pursuit of happiness." Today it is self-evident that some men are "more equal" than others and that there are many who without government intervention would not be able to live, to be free, or even to pursue-no less achieve-happiness. It may therefore be a necessary next step to acknowledge that the government, by the mandates of a Constitution that has shown a remarkable ability to grow with the times, has an affirmative obligation to create at least minimal conditions of freedom and that among these conditions is the freedom to decide when and whether to bring new life into the world. We all recognize that the government may not take life except by due process of law. Should not the government also have an equal duty not to deny the right to create life, on the one hand, nor to force the creation of life on the other by failing to make available information and supplies to those who without government assistance have no freedom of choice?

Whatever the answer to this question, and whether or not it stems from the Connecticut birth control case, that case and the history of birth control in this country clearly open up lines of inquiry, the developments and responses to which will have much to do, not only with the birth of humans, but also with the continuing process of the rebirth of freedom. 